As regards quinine administration in Burma, it may be 6afely asserted that 30-grain doses of the sulphate are not prescribed. So far as I am aware, 10 grains thrice daily is the usual practice, the doses recommended by Major Leonard Rogers, I.M.S., in his book "Fevers in the Tropics." I am aware of the fact that opinions still differ as to the dosage of quinine. For instance, at the recent Imperial Malaria Oonference held at Simla in October, 1909, Major C. Donovan, I.M.S., stated that he usually employed 30 grains of the sulphate for a dose, or 20 grains of the hydrochloride, or 10 grains of the acid hydrochloride. Major James, I. M S., on the other hand, favoured the "fractional method" of treatment and made some very valuable suggestions with reference to "problems relating to the use of quinine." $\mathrm{He}$ has brought ample evidence to prove that there is a great deal yet to be learnt as regards the proper dosage of quinine in cases of malaria. $H e$ has pointed out very emphatically that the matter is very complex, the success of the drug depending upon a number of factors about which we know little or nothing at present. The time of administration is all-important, because we know that the drug is immediately fatal to only one stage of the parasite-namely, to that stage which follows sporulation. It would take up too much of your valuable space to quote the many unsolved problems suggested by Major James, whose valuable contribution should be in the hands of all medical men interested in the subject of malaria and blackwater fever.

In regard to the quinine prophylaxis of malaria, different methods have been adopted. Major James recommends a small dose every evening, but admits that good results can be attained by other methods, as was obtained by Colonel G. F. W. Braide, I.M S., in the Punjab jails, where 15 grains were given once a week to each prisoner. The following figures show the results obtained in 1908 by me in the Myitkyina Military Police Battalion, the average strength in each year being a little over 1400 men. Admissions for malarial fever at headquarters and the eight permanent outposts :--

\begin{tabular}{|c|c|c|c|c|c|c|c|c|c|}
\hline & & & & & ndoor, & & or. & & \\
\hline & & & & $\cdots$ & 1602 & ...... & 337 & $\cdots$ & \\
\hline & & & & & 32 & & 10 & & \\
\hline
\end{tabular}

Ten grains of quinine sulphate dissolved in acid sulph. dil. and water were given by the mouth on two successive days, commencing from May and ending in December. During this year there were four cases of blackwater fever, the notes of which will be sent for separate publication.

What Dr. Frere says about small regular doses of quinine being used in Africa is not borne out by the observations recently made by a correspondent (Surg.-Lieut.-Col. I. M.S., Retd.) on pp. 29 and 30 of the Journal of Tropical Medione and Hygiene, dated Jan. 15th, 1910. He says : "Although I made scores of inquiries I tailed to meet anyone using quinine as a prophplactic who took more than 5 grains of the remedy daily. Very few took as much, the majority contenting themselves with 3 grains a day or with only occasional doses of 10 grains or so whenever they feel run down; others again took 15 grains nnce or twice a week, and so on. Several men, from indifference or inertia, frequently omitted to take any quinine whatever for days together, while a few professed to have no faith in its protective power and did not take it at all. No wonder that under such circumstances quinine prophylaxis of malaria on the West Crast of Africa has been a failure, and that deaths from blackwater fever still are, as in the past, of constant occurrence." This emphasises the fact that the problems sugyested hy Major Jarnes should receive careful and early consituration, but there will probanly be no uniformity of prastive annongst metical men in the quinine prophylaxis and treatiment of malaria till such time as the points raised by him are -atisfacturily settled

I must aprologise for the length of this letter, but I trust that I have sncreeded in showing that the question of blackwater tever and the correct treatment and prophylaxis of malarita are receiving careful attention in India and Burma. It sometimes hapuens that patients have their own ideas on treatment and very likely the civil servant from Burma was ont of thest l'he statements made by such patients are apt inalvettently to callse unmerited reflections of ignorance or neglect on the part of their medical attendants. I am. Sir, vours faithfully.

LAWRENCH G. FINT, M. B., C.M. EAin.,

July 21st, 1910 . Civil surgeon, Myau igmya, Lower Burina.

\section{THE CAUSATION OF DIFFUSE LIPOMA OF THE NECK.}

To the Editor of THE LANCET.

SIR, - I shall be much obliged if you will kindly assist me in an inquiry which I have at present in hand. Your readers are doubtless well familiar with the condition of diffuse lipoma of the neck and other regi ns, which we have been accustomed of late (following, I think, the lead of Mr. Morrant Baker) to associate with beer-drinking. Has this condition come under observation in any of the domestic animals? I have at present two good examples of it in asses, and I am told that others may be found if looked for. The condition should be sought, if I am not mistaken, in castrated males which have been well fed.

If any of your readers can refer me to anything which has been written on the subject or to examples which they have themselves observed I shall be much obliged. Some may possibly remember that in my recent paper before the British Medical Association I made especial reference to this region in connexion with paleogenetic speculations. I am, Sir, yours faithfully.

Haslemere, Sept. 4th, 1910. JONATHAN HUTCHINSON.

\section{THE OUTBREAK OF CEREBRO-SPINAL MENINGITIS IN LEICESTERSHIRE. \\ To the Editor of THE LANCET.}

SIR,-As this outbreak of cerebro-spinal meningitis has caused much writing in the press and sundry statements have been attributed to the Local Governmer:t Board inspector, 1 would ask those who are interested in the question to await the publication of the full notes. These will be published by me, so far as my cases are concerned, when I am able to add the report of the examinations by the several bacteriologists who have the matter in hand.

I. am, Sir, yours faithfully,

GUY C. B. AThINSON.

Long Clawson, Melton Mowbray, Sept. 6th, 1910

\section{THE TREATMENT OF RINGWORM. To the Editor of THE LANCET.}

SIR, - I was agreeably surprised to read Dr. J. Mackinnon's letter re action of formalin 40 per cent. solution on ringworm. Dr. Mackinnon does not specify if he used formalin with such success in ringworm of the head. Its use he appears to limit to tinea corporis, which most medical men admit sometimes yields to the domestic remedy ink. In my practice I have found formalin very deadly to fleas as well as to flies. I am, Sir, yours faithfully, SANDY MACPherson.

\section{THE JAPAN-BRITISH EXHIBITION: AWARDS.}

To the Editor of THE LANOET.

SIR, - On July 9th the name of our firm appeared in the List of Awards as the only recipients of the Grand Prix for disinfectants, and we duly announced that fact by an advertisement in the columns of your journal. We now learn (eight weeks after the original publication of the list) that within the last few days a similar distinction has been conferred upon another firm of manufacturers, making our statement erroneous as at the present time. We now ask the courtesy of your columns to correct our statement, which was, of course, made in good faith and in no sense intended to mislead. Yours \&e.

For Jeyes' Sanitary Compounds Co., LImited, WM. Planner, Secretary.

Cannon-street, I.C., Sept. 3rd, 1910.

\section{ON THE NOTIFICATION OF CONSUMPTION}

\section{To the Editur of THE LANCET.}

SIR, - I see that in THE LANCET of August 20th a correspondent, Dr. J. Cunningham Bowie, comments upon a letter from me which you published in your issue of August 6th, and says that, he would feel much obliged by my replying to three questions which he propounds at the close of his communication. Before stating these be points out, appa. rentily as a ground of complaint against me, that I have not disproved a single fact or controverted a single statement in 